\title{
Study of the Covid-19 Related Quarantine Concept as an Emerging Category of a Linguistic Consciousness
}

\section{Исследование концепта коронавирусного карантина как новой категории языкового сознания}

\author{
Vitalii Shymko ${ }^{1}$ \\ DSc. in Psychology, \\ Professor
}

fessor
Виталий Шимко

доктор психологических наук, профессор

E-mail:shymko@outlook.com

https://orcid.org/0000-0003-4937-6976

Anzhela Babadzhanova ${ }^{2}$

Ph.D. in Psychology
Анжела Бабаджанова ${ }^{2}$

кандидат психологических наук

E-mail: babadjanova.a@gmail.com

https://orcid.org/0000-0002-5430-6342

${ }^{1}$ Pereiaslav-Khmelnytskyi

Hryhorii Skovoroda State

Pedagogical University

$\square$ 30, Sukhomlynskyi Str.,

Pereiaslav-Khmelnytskyi, Kyiv Reg.,

Ukraine, 08401

${ }^{2}$ «Golden Tile» Group of Companies

$\triangle 50$, Mashynobudivna Str., Kyiv,

Ukraine, 03067
${ }^{1}$ ДВНЗ «Переяслав-

Хмельницький державний педагогічний університет імені Григорія Сковороди» $\triangle$ вул. Сухомлинського, 30, Переяслав-Хмельницький, Київська обл., Україна, 08401

${ }^{2}$ Группа компаний «Golden Tile» $\triangle$ ул. Машиностроительная, 50, Киев, Украина, 03067

Original manuscript received May 02, 2019

Revised manuscript accepted September 28, 2020

ISSN 2309-1797 (print) / 2415-3397 (online) 


\section{ABSTRACT}

Objective. Study of the Covid-19 related quarantine concept as an emerging category of linguistic consciousness of Ukrainians.

Materials \& Methods. The strategy of the study is based on the logical and methodological concept of inductivism. Respondents were asked to write down their own understanding of the quarantine, formulate an appropriate definition and describe the situation, which in their opinion is the exact opposite to quarantine. Respondents also assessed how much their psychological well-being, their daily lifestyle during quarantine had changed, and ranked their preferences for the quarantine strategies proposed to them. A discursive analysis was applied to the obtained texts, as a result of which nine discourses were identified. These data, along with some sociodemographic characteristics were subjected to multidimensional mathematical and statistical processing.

Results. Covid-19 related quarantine is represented in the linguistic consciousness of Russian-speaking Ukrainians by a discursive field, which includes at least nine recognizable, semantically autonomous discourses. Empirically discovered such phenomenon as - inter-discourse semantic dissociation. Its essence is a statistically significant reduction in the probability of some discourses appearing in the texts when others are being actualized there. This feature is associated with the innate negativity of the language and determines the semantic biasing of the quarantine concept. Inter-discourse semantic dissociation, as well as the influence of non-discursive factors constitute the discursive formation of the quarantine concept, which is qualitatively characterized by the hierarchical relationship of its components. At the same time, it was revealed that part of the discourses interacting "horizontally" are indirectly associated "vertically", which forms the stable semantic core of the quarantine concept. Partial empirical confirmation has been found of the previously put forward assumptions about: (a) the existence of such a relationship between discourses and psychological defense mechanisms (as character-forming factors) that contributes to the hierarchical structure construction of discursive formations; (b) the differential nature of discourses and mechanisms of psychological defenses interaction, which makes it possible to single out the discursive aspect in a characterological profile and consider a discourse as an operator of characterological semantics.

Conclusions. An empirical study made it possible to form a primary idea of the substantive and structural semantic features of the quarantine concept, as an emerging category of linguistic consciousness of Ukrainians. The results obtained have a potentially useful application perspective. Thus, when implementing anti-epidemiological measures, it is important to consider the studied features of the discursive formation hierarchical structure of the quarantine concept, since discursive semantics are associated with cognitive focusing, which, in turn, affects the behavior direction and its upshots.

Key words: quarantine, Covid-19, coronavirus, discourse, linguistic consciousness, semantics, dissociation, character. 


\section{Introduction}

The Covid-19 coronavirus pandemic has become an unprecedented challenge for most modern human beings. According to the criteria of rapid spread, geographical coverage, dynamics of morbidity and mortality, the closest historical analogue is the events of 1918-20, called the Spanish flu (Rosenwald, 2020). Despite to the century of scientific and technological acceleration that has passed since then, the main global response to the pandemic remains quarantine yet. The first half of 2020 convincingly has demonstrated the non-alternative nature of such a method of controlling morbidity, especially in the early stages of the disease spread. This has focused the interest of the scientific international community towards the various aspects of quarantine, as a socio-psychological and organizational-economic phenomenon. So, along with the impact on the epidemiological dynamics, the functioning of society itself, the behavior and well-being of people under conditions that instantly gained status 'new normal' have been studied (Brooks, 2020; Haletska, 2020; Holmes, 2020; Long, 2020; Moloney, K. \& Moloney, S., 2020; Nussbaumer-Streit et al., 2020; Parmet \& Sinha, 2020; Sorooshian, 2020; Suresh, 2020; Volpert et al., 2020; Wanga et al., 2020; Webster et al., 2020; WilderSmith \& Freedman, 2020 et al.).

Most scientists rightly believe that the successful implementation of quarantine involves behavioral, organizational, informational and value synchronization of the actions by millions of people. However, at the same time, the linguistic tools of such synchronization are mainly being left outside the framework of the first wave of social and humanitarian studies. On the one hand, in the research community itself there is no consistency pertaining the semantic field of the term quarantine. On the other hand, the meaning of this concept for modern people remains almost unexplored by scientists. The coronavirus pandemic not only actualized the corresponding word, but rather led to the formation of a new category in the linguistic consciousness of mankind. Our study is devoted to an empirical research of some semantic features of the quarantine concept, as an emerging phenomenon in Ukrainian society. This article presents the results that we perceive as the most significant, both scientifically and theoretically, and from an applicability point of view as well. 


\section{Methods and Techniques of the Research}

The strategy of our study is based on the inductive logical and methodological concept. Such a choice was made due to, firstly, unexampled events that determined the subject of our study, i.e. the content and structural semantics features of the Covid-19 related quarantine concept (hereinafter - quarantine) as an emerging category of a linguistic consciousness. Secondly, because of obvious applicability importance of such research for the respective socio-epidemiological, organizational, economic issues, etc. In this regard, we compiled a sample of respondents who were employed and worked during the quarantine period (104 people in total) in several regions of Ukraine (Kyiv, Dnipro, Kharkiv, Odessa, Lviv, Rivne, Mukachevo). The age range was from 21 to 62 years. Gender distribution $-47.1 \%$ of women. All are ethnic Ukrainians, bilinguals (Ukrainian and Russian) with higher education. Field part of the study was conducted in the second half of May 2020, which means that all respondents spent more than 60 days under national quarantine conditions, started in Ukraine on March 11, 2020. Most of the respondents worked during the quarantine period, visiting offices and other places of professional activity. 13.5\% - were on short-term of self-isolations (from 1 to 15 days). One respondent self-isolated himself for 50, and two - for 56 days. According to the participants' self-reports, no one in the indicated period had been officially diagnosed with any diseases and had not experienced any sickness symptoms at the time of the study. $6.7 \%$ of respondents said that among their personal environment have been some acquaintances (family members, close friends, work colleagues, etc.) who got sick on coronavirus during quarantine (from 1 to 7 people).

Each respondent was asked to set out their own understanding of quarantine, i.e. formulate an appropriate definition in written. After that, respondents described the situation, which is the exact opposite of quarantine (anti-quarantine). This task was provided and used by us for: (a) subjective semantics clarification of quarantine definitions; (b) making reconstruction of the implied meanings of quarantine when the respondents borrowed the corresponding definitions from the Internet (14 such cases were found in total, which amounted to $13.5 \%$ of the sample). Respondents also assessed how much their psychological well-being and everyday life routine had been changed during quarantine 
and ranked their preferences for the list of quarantine strategies proposed by us: military like (tough and decisive actions); systemic (comprehensive and controlled measures); democratic (permissive and selective policies); social protection (collective provision and security). Specified tasks and some socio-demographic questions were aggregated in the questionnaire «My Quarantine» (in Russian). Its sample along with detailed calculations of multidimensional mathematical and statistical processing (IBM SPSS Statistics, Version 26.0.0.1) of the survey results, are publicly available at Harvard Dataverse (Shymko \& Babadzhanova, 2020).

Like in any other inductive oriented research, it is impossible to completely abandon some hypothetical-deductive initial premises, the need for which is objectively actualized by necessity of choosing methods and forming tools for the data collection, processing and further interpretations of obtained statistical results. In particular, the quarantine strategies mentioned above in the «My Quarantine» questionnaire (Shymko \& Babadzhanova, 2020: HO7EWG) were created by us taking into account some characterological features of speech activity and were intended to study the possible connection between subjective quarantine conceptualizations and psychological defense mechanisms (Reich, 1990). Furthermore, the respondents' quarantine definitions were classified and quantified based on Foucault's theory of such a psycholinguistic category as a discourse: «...discourse is constituted by a group of sequences of signs, in so far as they are statements, that is, in so far as they can be assigned particular modalities of existence... The term discourse can be defined as the group of statements that belong to a single system of $<$ discursive $>$ formation; thus I shall be able to speak of clinical discourse, economic discourse, the discourse of natural history, psychiatric discourse» (Foucault, 1972: 107-108). Herewith the practical side of discourses identification in the texts studied was realized by us through recognizing stable semantic autonomies generated by dispersions of verbal meanings.

This work was carried out in three steps. On the first and second ones the experts were engaged (four scientists, practical researchers with more than 20 years of professional background in the field of applied psycholinguistics). At the first step, each expert independently analyzed every text and formed the initial classification of the identified discourses. Then these discourses were compiled together and in such 
a way a general list of 23 discourses was created. At the second step, the experts had discussed the general list, clarified the semantics of previously derived discourses and achieved terminological unification, as a result of which the list was reduced to nine positions that form the discursive field of the quarantine concept (Table 1). On the third step the hierarchical cluster analysis had been applied, the results of which (Shymko \& Babadzhanova, 2020: J5IAHJ) substantiated the expediency of combining the fourth, fifth and eighth discourses (Table 1) into one discourse, which we designated as HEALTH PRESERVATION. The data array was accordingly rearranged and further processing (frequency, correlation, binary logistic and ordinal regression analysis) was carried out within the framework of the seven-discourse model.

Table 1. Discursive field of quarantine concept

\begin{tabular}{|c|c|c|}
\hline No & $\begin{array}{l}\text { (*) Numbering and } \\
\text { denomination of discourses }\end{array}$ & Semantic content of discourses derived by experts \\
\hline 1. & CONTACT RESTRICTION & $\begin{array}{l}\text { Restriction/control of contacts, meetings and movements } \\
\text { as contacts motivators, its amplifiers and intensifiers. } \\
\text { Aspect of forced passivity. }\end{array}$ \\
\hline 2. & $\begin{array}{l}\text { SANITATION AND } \\
\text { HYGIENE }\end{array}$ & $\begin{array}{l}\text { Sanitary and hygiene products and their use, preventive } \\
\text { measures. Quarantine behavior (awareness, caution, } \\
\text { discipline), including social distancing, remote work and } \\
\text { self-isolation. The internality aspect. Activity. }\end{array}$ \\
\hline 3. & ISOLATION OF INFECTED & $\begin{array}{l}\text { Isolation of infected and sick people, as well as those } \\
\text { who have been in contact with them (ones suspected of } \\
\text { being infected). Segregation aspect. }\end{array}$ \\
\hline 4. & $(* *)$ TOTAL ISOLATION & $\begin{array}{l}\text { Isolation of healthy people. Bilateral, mixed, mass, } \\
\text { territorial and/or any non-specified isolation. }\end{array}$ \\
\hline 5. & $(* *)$ HEALTH CARE & $\begin{array}{l}\text { Preservation, maintenance and promotion of health. } \\
\text { Treatment of patients, contribution to their recovery. } \\
\text { Medicines and drugs in the aspect of the means of } \\
\text { recovery/maintaining health. }\end{array}$ \\
\hline 6. & VIRUS DISSEMINATION & $\begin{array}{l}\text { Prevention (restriction, control) of the spread of the } \\
\text { virus (disease). Socio-geographical aspect. Reducing the } \\
\text { number of infected people and/or patients. }\end{array}$ \\
\hline 7. & LIFESTYLE CHANGES & $\begin{array}{l}\text { Change in the habitual (everyday) way of life of } \\
\text { people and society on the whole (work, home life, } \\
\text { entertainment, etc.). Not specified limitations and } \\
\text { restrictions of life activity. Discomfort and frustration, } \\
\text { as indicators of a reaction to a violation of the regular } \\
\text { lifestyle. }\end{array}$ \\
\hline
\end{tabular}


Study of the Covid-19 Related Quarantine Concept as an Emerging...

8. (**) RIGHTS

AND FREEDOMS

INFRINGEMENT

9. BUREAUCRATIC

RESPONSE
Restriction (infringement, deprivation) of human rights and freedoms in connection with quarantine. The repressive aspect with «justifying» rationalization (for a good cause, in the name of a noble/useful goal, etc.).

The introduction of official standards and regulations by the authorities. Socio-legal and medical-infrastructural aspects of state (societal) regulation. Epidemic statistics and other studies. Organization of public awareness (alert system).

Note: (*) - hereinafter in the tables and statistical reports of the SPSS it is necessary to distinguish the numbering of discourses in the datasets for 9 and 7 discourses respectively;

$(* *)$ - in wake of cluster analysis, the marked discourses were combined under the name HEALTH PRESERVATION and the dataset were rearranged accordingly, which caused a change in the general numbering of discourses in the statistics posted in the repository.

Separately we note that for the purpose of discourses quantification a binary nominal scale was used in the dataset ( 1 - THERE IS DISCOURSE; 0 - NO DISCOURSE), regardless of the amount of corresponding text units (words) and compositional linguistic features of the discourse's textual manifestations. Despite the obvious hierarchical relations between the studied discourses, in this publication we do not dwell on the issue and confine ourselves to setting out the most basic semantic characteristics of the discursive field and its structural organization. The reason is the excessive amount of the corresponding results, a comprehensive description of which would require several separate reports. In the further parts of this article, the most important generalizations are given that deserve attention from the point of view of their mathematical and statistical significance. Appropriate specifying parameters and details, as noted, are available online for review and study (Shymko \& Babadzhanova, 2020).

\section{Results}

The results are focused on the discourses that were distinguished by experts in the textual definitions of quarantine. The first orienting idea about the functional structure of the discursive field, as well as the existence and nature of the discourses interconnections with other parameters studied, can be formed from the results of correlation 
analysis (Shymko \& Babadzhanova, 2020: ZORR3U). At the same time, binary logistic regression is the most interesting and informative one. Its statistically significant results are presented in Table 2 . Note that in addition to the traditional criteria for assessing regression models fitness, the Hosmer and Lemeshow Goodness-of-Fit Test was also used (in all cases we found out $p>.050$, i.e., the hypothesis of acceptable levels of models' fitness were accepted).

Table 2. Binary logistic regression (dependent variables - discourses)

\begin{tabular}{|c|c|c|c|c|c|c|c|}
\hline $\begin{array}{r}\text { Dependent variables } \\
\text { (discourses) }\end{array}$ & 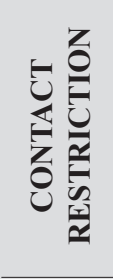 & 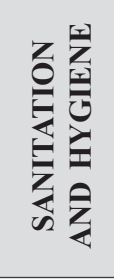 & 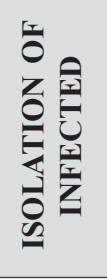 & 学 & 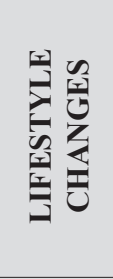 & 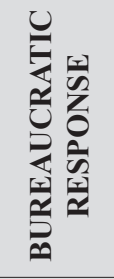 & 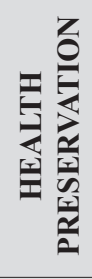 \\
\hline parameters & \multicolumn{7}{|c|}{ Regression coefficient $\boldsymbol{B}$ (sig. $\boldsymbol{p}<\mathbf{0 . 0 5}$ ) } \\
\hline CONTACT RESTRICTION & & $\begin{array}{l}-2.775 \\
(0.037)\end{array}$ & & & & $\begin{array}{r}-6.778 \\
(.001)\end{array}$ & \\
\hline $\begin{array}{l}\text { SANITATION AND } \\
\text { HYGIENE }\end{array}$ & & & & $\begin{array}{r}-6.751 \\
(.000)\end{array}$ & & & \\
\hline ISOLATION OF INFECTED & & & & $\begin{array}{r}-2.722 \\
(.005)\end{array}$ & & $\begin{array}{r}-4.334 \\
(.006)\end{array}$ & \\
\hline VIRUS DISSEMINATION & $\begin{array}{r}-2.964 \\
(.006)\end{array}$ & $\begin{array}{r}-5.722 \\
(.001)\end{array}$ & & & $\begin{array}{r}-3.589 \\
(.002)\end{array}$ & $\begin{array}{r}-3.458 \\
(.008)\end{array}$ & \\
\hline $\begin{array}{l}\text { LIFESTYLE } \\
\text { CHANGES }\end{array}$ & & & & & & & \\
\hline $\begin{array}{l}\text { BUREAUCRATIC } \\
\text { RESPONSE }\end{array}$ & $\begin{array}{r}-6.184 \\
(.001)\end{array}$ & & & & & & \\
\hline HEALTH PRESERVATION & $\begin{array}{r}-3.798 \\
(.010)\end{array}$ & & & $\begin{array}{r}-2.750 \\
(.003)\end{array}$ & $\begin{array}{r}-3.530 \\
(.012)\end{array}$ & $\begin{array}{r}-4.929 \\
(.003)\end{array}$ & \\
\hline Number of discourses & $\begin{array}{l}4.586 \\
(.000)\end{array}$ & $\begin{array}{l}3.217 \\
(.000)\end{array}$ & & $\begin{array}{l}3.103 \\
(.000)\end{array}$ & $\begin{array}{l}2.223 \\
(.012)\end{array}$ & $\begin{array}{l}4.561 \\
(.000)\end{array}$ & \\
\hline $\begin{array}{l}\text { Changes in everyday } \\
\text { life }\end{array}$ & $\begin{array}{l}1.787 \\
(.006)\end{array}$ & & $\begin{array}{l}-.907 \\
(.049)\end{array}$ & & & & \\
\hline Self-isolation (days) & & & & & & & $\begin{array}{c}.064 \\
(.050)\end{array}$ \\
\hline $\begin{array}{l}\text { (*) Model coefficient, } \chi 2 \\
\text { (sig. p) }\end{array}$ & $\begin{array}{r}50.702 \\
(.000)\end{array}$ & $\begin{array}{r}38.625 \\
(.000)\end{array}$ & $\begin{array}{l}4.386 \\
(.036)\end{array}$ & $\begin{array}{l}51.613 \\
(.000)\end{array}$ & $\begin{array}{c}40.662 \\
(.000)\end{array}$ & $\begin{array}{c}53.023 \\
(.000)\end{array}$ & $\begin{array}{l}6.550 \\
(.010)\end{array}$ \\
\hline $\begin{array}{l}\text { (**) Model Summary } \\
\text { (Nagelkerke R Square) }\end{array}$ & .648 & .599 & .078 & .603 & .564 & .686 & .109 \\
\hline
\end{tabular}


Study of the Covid-19 Related Quarantine Concept as an Emerging...

(***) Predictive value

(overall \% correct)

$86.0 \%$

$90.7 \% \quad 80.2 \%$

$82.6 \%$

$86.7 \% \quad 88.4 \%$

$79.1 \%$

Note: (*) - displays the significance of improving the regression model;

$(* *)$ - part of the dispersion covered by logistic regression $(\max =1)$;

$(* * *)-$ the proportion of reliable predictions based on the model.

A general assessment of the results draws attention to several specific points. Firstly, statistically reliable predictors of discourses, predominantly, turned out to be other discourses. Moreover, the corresponding relationships with independent variables have been always negative. That is, for example, the presence in the quarantine definition of discourses VIRUS DISSEMINATION and / or CONTACT RESTRICTION significantly reduces the probability of the SANITATION AND HYGIENE discourse emergence. This feature resembles the data distribution structure observed when ranking variables. For example, in our study, respondents had rated their preference out of four quarantine strategies. At the first step of the assessment, when one of the strategies, for example, was evaluated by maximum rank (4), the other three automatically «moved down» to a lower ranking position. At the next evaluation step, one of the remaining strategies received rank (3), which again lowered the ranking position of the two other alternatives and so on. Such an assessment technology naturally determines the negativity of statistical relationships between ranked variables. However, we have observed a similar picture in a fundamentally different situation - the distribution of binomial variables, the values of which in this case objectively could not depend on the experimental conditions and the measuring scale used for the parameter. In our opinion, this might indicate the naturally presence of such discourse interaction mechanism, which is similar to the just described influence of the ranking procedure onto the empirical data distribution. In other words, we suggest that discourses are hierarchically organized. In the next section of this article, we will return to discussing this nuance, and now we continue to review the general results of binary logistic regression.

Secondly, the NUMBER OF DISCOURSES appeared to be a positive predictor for the most discourses. However, there are two exceptions - ISOLATION OF INFECTED and HEALTH PRESERVATION. The prediction of these parameters is not related to the NUMBER OF DISCOURSES. The described statistical features 
suggest that the variables reliably dependent on the NUMBER OF DISCOURSES (i.e. - CONTACT RESTRICTION, SANITATION AND HYGIENE, VIRUS DISSEMINATION, LIFESTYLE CHANGES, and BUROCRATIC RESPONSE) are associatively related between themselves. And that lead to an increase in the probability of their emergence as the pithiness of definitions grow. We believe that these discourses form a stable semantic core of the quarantine concept in the linguistic consciousness of respondents.

Therefore, thirdly, those discourses and their predictors that are not included in the specified core are of particular interest. The dependent variable ISOLATION OF INFECTED connected with the non-discursive predictor CHANGES IN EVERYDAY LIFE, the negativity of which (see Table 2) is conditional. So, this parameter has an ordinal measuring scale that displays the degree of changes in everyday life routine, according to the respondents' ratings: from 1 no changes to 4 - dramatic changes (Shymko \& Babadzhanova, 2020: HO7EWG). Thus, the probability of the ISOLATION OF INFECTED discourse emergence in the quarantine definition is the higher, the less changes in the daily life of respondents have been and vice versa. This feature makes us suggest the play of some egocentric attitude of the respective respondents, manifested by the principle: «quarantine is for infected ones». In other words, we are implying on reluctance of those respondents to identify themselves with the diseased ones. An indirect confirmation of the indicated egocentrism of this category of respondents might be found as well in the following observation. The discourse ISOLATION OF INFECTED, in turn, acts as a negative predictor in relation to the discourses VIRUS DISSEMINATION and BUREAUCRATIC RESPONSE (see Table 2). That is, respondents who had not been experiencing changes in everyday life routine and discussing isolation of infected ones are not inclined to actualize any other collective aspects of the quarantine problem.

It is noteworthy that the non-discursive criterion CHANGES IN EVERYDAY LIFE also acts as a positive predictor for the discourse CONTACT RESTRICTION, increasing its probability together with the two already mentioned negative predictors (VIRUS DISSEMINATION and BUREAUCRATIC RESPONSE) and another negative one HEALTH PRESERVATION (see Table 2). At the same time, the last parameter as a dependent variable is positively predicted by 
independent non-discursive variable - SELF-ISOLATION (DAYS). That is, quarantine concept will most likely be defined in the context of maintaining and promoting health by those respondents who have got some experience of being on self-isolation.

\section{Discussions}

To interpret the results (Table 2), let us return to the hierarchy of discourses mentioned above. More often about hierarchy it is customary to speak in axiological, motivational-needful, event-sequential, spatiotemporal relation, etc. All these are examples of hierarchies with a fundamentally positive (affirmative) architecture. In psycholinguistics, in our opinion, it is necessary to consider the negative nature of the language, especially when studying the verbal categories of consciousness: «Instead of preexisting ideas then, we find in the foregoing examples values emanating from the system. When they are said to correspond to concepts, it is understood that the concepts are purely differential and defined not by their positive content, but negatively by their relations with other terms of the system. Their most precise characteristic is in being what the others are not» (Saussure, 1959: 117). We believe that the negative inter-discourse relationships detected by us using binary logistic regression (Table 2) reflect Saussure's quoted position.

Summarizing the results of binary logistic regression and considering them in the context of other statistical observations (Shymko \& Babadzhanova, 2020), we are inclined to make a conclusion that such a negativity has a certain specificity and is adjacent next to other (positive) factors that form the quarantine concept semantics. So, on the one hand, inter-discourse relations are realized not so much by negative association scenario as according to the principle of dissociation. Here, by dissociation we mean the phenomenon observed in our study: the actualization of one discourse is accompanied by a statistically significant decrease in the probability of another (others) appearances in the text, which in practice means the factual exclusion of these discourses from the quarantine concept. This feature determines the tendentiousness (biasing) of the quarantine concept semantics. At the same time, we assume that such a dissociative «withdrawal» of semantics is not specific for quarantine concept and occurs during the formation 
of other linguistics concepts as well. Furthermore, we suggest this mechanism generally takes part in the verbal-logical operations by the means of linguistic consciousness categories. In this regard, we propose to recognize the corresponding discursive phenomenon and designate it as inter-discourse semantic dissociation (hereinafter - dissociation).

Along with the above, we believe that dissociation arises not only as a result of Saussure's negativism of the language, but also as a result of the natural process limitations of linguistic consciousness (Miller, 1956), which implements informational metabolism. Having conditionally designated the information maximum, which theoretically can be produced by a specific respondent in our experiment for -1 , the described inter-discourse semantic dissociation will have the following logical and mathematical expression:

$$
1 \geq D 1=\frac{1}{1-(D 2+D 3)}+\frac{1}{\sum k}
$$

In the above formula: D1, D2, D3 - discourses; $\mathrm{k}$ - non-discursive factors affecting the probability of certain discourses appearing in the quarantine concept, as in the case we observed with the example ISOLATION OF INFECTED and HEALTH PRESERVATION (see Table 2).

On the other hand, returning to the identified features of the NUMBER OF DISCOURSE predictor, one cannot help but assume the existence of an association-like connection. This, at first glance, creates a paradox - dissociatively interacting discourses are simultaneously related associatively. This obvious contradiction can be resolved by a systemic distinction of layers (semantic spaces), where the indicated dissociations and associations have taken place. The horizontal layer is represented by the functional interaction of discourses as structural components of the system (blue arrows with large dashed lines, Fig. 1). Note that at this level, the system also includes non-discursive factors (indicated in italics, Fig. 1). The vertical layer is formed through the meaning contribution by each discourse to the semantics of the quarantine concept as a supersystem. Thus, horizontal inter-discourse dissociation does not prevent the formation of positive connections vertically integrated associations that are formed indirectly through the category of the supersystem (quarantine). 


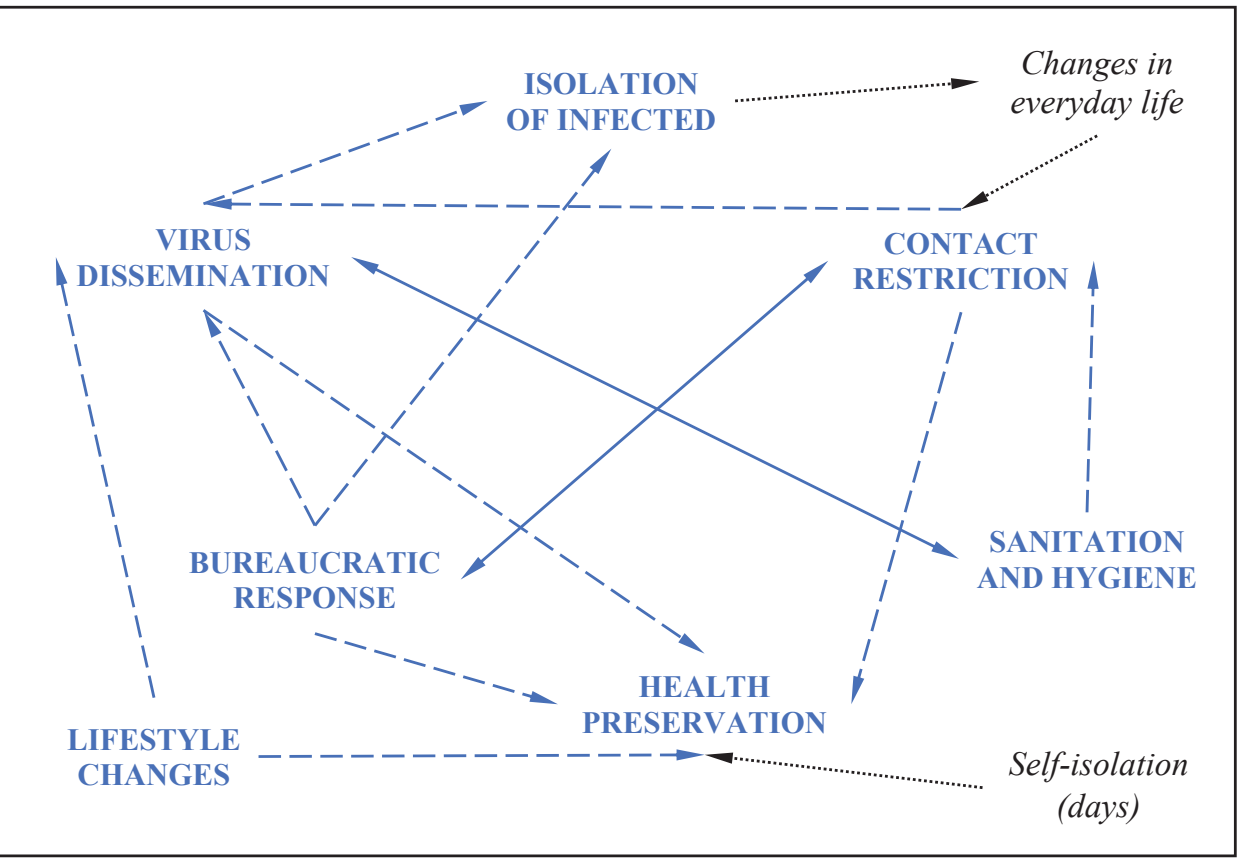

Fig. 1. The hierarchical structure of the discursive formation of the quarantine concept

In the proposed scheme (Fig. 1), the blue arrows on the inter-discourse connections indicate the object of dissociation (deactualized one). Note that there have been two pairs of discourses with two-way blue arrows: VIRUS DISSEMINATION and SANITATION AND HYGIENE, as well as BUREAUCRATIC RESPONSE and CONTACT RESTRICTION. The bilateral nature of dissociation, in our opinion, indicates of opposition-like relations between the respective discourses. Unidirectional dissociation, as discussed above, is due to the negativity of the language and the process limitations of informational metabolism as we prone to suggest. Although in the case of bilateral dissociation, it is logical to assume the participation of additional factors in the hierarchization of inter-discourse relationships. The stated hierarchical features impart to the discursive field a specific organization, which transforms the field into a discursive formation of the quarantine concept (Fig. 1).

We believe that the proposed view of quarantine as a semantic category of linguistic consciousness might have a potentially useful 
applied perspective. For example, when conducting mass alerts of citizens, organizing educational communication of health authorities with the population, introducing a quarantine regime at enterprises and institutions, etc., it is important to consider that the rhetoric about controlling of the virus spreading automatically deactivates the topic of sanitary and hygienic measures. Obviously, discursive semantics is associated with cognitive focus, which, in turn, affects the direction and consequences of proper behavior. Therefore, considering the structural and semantic features of the discursive formation (Fig. 1) in above cases could help increase the productivity and effectiveness of informational anti-epidemiological policies.

Returning to the question of inter-discourse opposition-like relations, one ought to note the following. We did formulate a hypothesis regarding the nature of this phenomenon by researching the predictive effect of studied discourses on such dependent variables as DYNAMICS OF WELL-BEING, CHANGES IN EVERYDAY LIFE and respondents' preferences of quarantine strategies. So, an ordinal regression analysis was carried out (Table 3), according to which the VIRUS DISSEMINATION and the BUREAUCRATIC RESPONSE discourses were found among the reliable predictors of the SYSTEMIC STRATEGY choice by respondents. The latter, according to our initial assumptions at the planning stage of the study, should have been the preferred choice of respondents with an obsessive-compulsive (pedantic) type of character (Reich, 1990). The leading mechanism of psychological defense of this character type is an affect isolation (Reich, 1990). The work of this protective mechanism is accompanied by the disengagement of ego-consciousness from emotional experiences and the formation of intrusive patterns of cognitive activity, which rationalized by representatives of an appropriate character as means of streamlining, structuring, controlling and ensuring predictability of their lives under uncertainty and chaos conditions.

Substantial correspondence of the discourses semantics of VIRUS DISSEMINATION and BUREAUCRATIC RESPONSE to cognitive and behavioral features of the character type under consideration is obvious and indicative. Moreover, both of these discourses found a power of statistically significant negative prediction of respondents' preferences for a DEMOCRATIC STRATEGY (see Table 3). This strategy, according to our assumptions, is associated with the antipode 
of the obsessive-compulsive character - the hysterical (demonstrative) one (Reich, 1990), which psychodynamics is due to the mechanism of psychological defense - bodily-motor reaction (Reich, 1990). In this regard, it is logical to suppose the existence of: (a) the relationship between discourses and psychological defense mechanisms, that contributes to the construction of hierarchical structure of discursive formations; (b) the differential interaction of discourses and psychological defense mechanisms, that allows us to assert of the discursive aspect of the characterological profile and to consider a discourse as an operator of characterological semantics.

Table 3. Ordinal regression (predictors - discourses)

\begin{tabular}{|c|c|c|c|c|c|c|c|}
\hline \multirow{3}{*}{\multicolumn{2}{|c|}{$\begin{array}{l}\text { Predictors } \\
\text { and model } \\
\text { parameters }\end{array}$}} & \multicolumn{4}{|c|}{ QUARANTINE STRATEGIES } & \multirow[b]{2}{*}{ 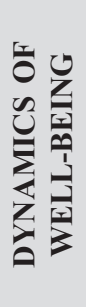 } & \multirow{3}{*}{ 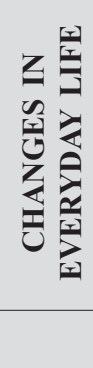 } \\
\hline & & 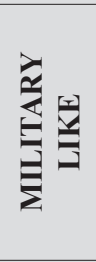 & $\sum_{\substack{n \\
\vdots \\
\infty}}^{U}$ & 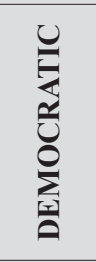 & 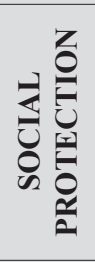 & & \\
\hline & & \multicolumn{5}{|c|}{ Estimate (sig. $p<0.05$ ) } & \\
\hline \multirow{7}{*}{ 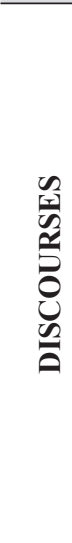 } & CONTACT RESTRICTION & & & & $\begin{array}{l}-.584 \\
(.039)\end{array}$ & & $\begin{array}{l}1.005 \\
(.048)\end{array}$ \\
\hline & SANITATION AND HYGIENE & & & & & & \\
\hline & ISOLATION OF INFECTED & & & & & & $\begin{array}{r}-1.221 \\
(.044)\end{array}$ \\
\hline & VIRUS DISSEMINATION & & $\begin{array}{l}1.961 \\
(.007)\end{array}$ & $\begin{array}{l}-.731 \\
(.016)\end{array}$ & & & \\
\hline & LIFESTYLE CHANGES & & & & & & \\
\hline & BUREAUCRATIC RESPONSE & & $\begin{array}{l}1.961 \\
(.009)\end{array}$ & $\begin{array}{l}-.755 \\
(.037)\end{array}$ & & & \\
\hline & HEALTH PRESERVATION & & $\begin{array}{l}2.141 \\
(.011)\end{array}$ & & & & \\
\hline \multicolumn{2}{|c|}{ DYNAMICS OF WELL-BEING } & & & & & & $\begin{array}{r}-1.065 \\
(.001)\end{array}$ \\
\hline \multicolumn{2}{|l|}{ Age } & $\begin{array}{l}-.090 \\
(.008)\end{array}$ & $\begin{array}{l}-.066 \\
(.016)\end{array}$ & & & & \\
\hline \multicolumn{2}{|c|}{ Gender } & & $\begin{array}{r}-1.625 \\
(.004)\end{array}$ & & & & \\
\hline \multicolumn{2}{|c|}{ Sick acquaintances } & & & & $\begin{array}{l}-.306 \\
(.010)\end{array}$ & $\begin{array}{c}.580 \\
(.047)\end{array}$ & \\
\hline
\end{tabular}


Дослідження кониепту коронавірусного карантину як нової...

\begin{tabular}{|c|c|c|c|c|c|c|}
\hline CHANGES IN EVERYDAY LIFE & & & $\begin{array}{l}-.431 \\
(.044)\end{array}$ & & & \\
\hline Self-isolation (days) & & $\begin{array}{l}-.069 \\
(.020)\end{array}$ & & & $\begin{array}{l}.121 \\
(.002)\end{array}$ & \\
\hline Quarantine (words) & & & & & $\begin{array}{l}-.078 \\
(.013)\end{array}$ & \\
\hline Anti-quarantine (words) & & & & & $\begin{array}{l}.045 \\
(.043)\end{array}$ & \\
\hline $\begin{array}{l}\text { (*) Model Fitting Information } \chi^{2} \text {, } \\
\text { (sig. p) }\end{array}$ & $\begin{array}{r}21.761 \\
(.040)\end{array}$ & $\begin{array}{r}24.739 \\
(.016)\end{array}$ & $\begin{array}{r}22.330 \\
(.050)\end{array}$ & $\begin{array}{c}(* * *) \\
13.135 \\
(.285)\end{array}$ & $\begin{array}{c}34.756 \\
(.002)\end{array}$ & $\begin{array}{r}23.762 \\
(.022)\end{array}$ \\
\hline (**) Pseudo R Square (Nagelkerke) & .241 & .275 & .241 & .133 & .362 & .243 \\
\hline
\end{tabular}

Note: $(*)$ - displays the significance of improving the regression model;

$(* *)$ - part of the dispersion covered by logistic regression $(\max .=1)$;

$(* * *)$ - There are significant amount of cells $>60 \%$ (i.e., dependent variable levels by observed combinations of predictor variable values) with zero frequencies, which affects the parameter $\chi^{2}$. In this regard, we assessed the respective quality of the current and other regression models by the Pearson criterion (in all cases, the level $p>.050$, necessary for the applicability of the analysis, was observed).

We emphasize that both theses can only be partially justified, since the results of ordinal regression (Table 3) do not allow extrapolating the corresponding conclusions to another dialectically interconnected pair of characters - narcissistic-phallic (dominant) and passive-feminine (passive), which form the structural basis of characterological diversity all together with mentioned above two types (Reich, 1990). We believe that for further empirical verification of these issues it is necessary to significantly increase the sample - both in quantitative and in linguisticcultural relations.

At the end of the publication, let us pay attention to some others interesting, in our opinion, results of ordinal regression. Positive changes in psychological well-being during the quarantine period are reliably predicted by the conciseness of the corresponding definitions and the reverse tendency in texts, that describing the opposite of quarantine (anti-quarantine). We believe, this feature correlates with the results of text studies within the framework of the psychosemiotic approach, which reveal the respective relationship between the texts volume and the subjective attitude of the authors to the textual content, whether pleasant or traumatic (Novikova-Grund, 2011). Another interesting observation is that the respondents' well-being improves significantly with the increase 
in the number of days spent on self-isolation and by the number of their sick acquaintances (see Table 3). It can be assumed that in the first case, respondents at least partially associated the corresponding experience with vacation (the time of self-isolation for each respondent was paid by the employers in full, regardless of the period of quarantine related absence out of the workplace). In the second case, in our opinion, it might be occurred a decrease of anxiety (and, as a result, improvement of well-being) due to the projective mechanism - «this did not happen to me». One way or another, both phenomena should be studied more deeply and thoroughly, because in our study there are no data that would allow confidently to avoid inadvertent speculations for the matter.

\section{Conclusions}

Covid-19 related quarantine is represented in the linguistic consciousness of Russian-speaking Ukrainians by a discursive field, which includes at least nine recognizable, semantically autonomous discourses. Empirically found and described such phenomenon as - inter-discourse semantic dissociation. Its essence is a statistically significant reduction in the probability of some discourses appearing in the texts when others are actualized there. This feature is associated with the negativity of the language and determines the tendentiousness (biasing) of the semantic filling of the quarantine concept. Inter-discourse semantic dissociation, as well as the influence of non-discursive factors constitute the discursive formation of the quarantine concept, which is qualitatively characterized by the hierarchical relationship of its components. At the same time, it was revealed that part of the discourses interacting «horizontally» are indirectly associated «vertically», that forms the stable semantic core of the quarantine concept.

Partial empirical confirmation has been found of the previously put forward assumptions about: (a) the existence of such a relationship between discourses and psychological defense mechanisms (as characterforming factors) that contributes to the hierarchical structure construction of discursive formations; (b) the differential interaction of discourses and mechanisms of psychological defenses, that makes it possible to single out the discursive aspect of the characterological profile and consider discourse as an operator of characterological semantics. 
We consider the prospects for further studies of the quarantine concept with, firstly, an increasing in the empirical sample, both in quantitative and linguistic-cultural relations and providing the possibility of comparative cross-ethnic research of the actual subject matter. Secondly, a deeper study of the influence on the quarantine concept semantics by the corresponding category of non-discursive factors, including the differential psychological characteristics of linguistic consciousness subjects.

\section{References}

Brooks, S.K. et al. (2020). The psychological impact of quarantine and how to reduce it: rapid review of the evidence. The Lancet, 395(10227), 912-920. https://doi. org/10.1016/S0140-6736(20)30460-8

Foucault, M. (1972). Archaeology of knowledge and the discourse on language. New York: Pantheon.

Haletska, I. et al. (2020). Quarantine April in Ukraine: thoughts, experiences, behaviour faced with the threat of COVID-19. PSYCHOLOGICAL JOURNAL, 6(5), 18-36. https://doi.org/10.31108/1.2020.6.5.2

Holmes, E.A. et al. (2020). Multidisciplinary research priorities for the COVID-19 pandemic: a call for action for mental health science. The Lancet Psychiatry, 7(6), 547-560. https://doi.org/10.1016/S2215-0366(20)30168-1

Long, N.J. et al. (2020). Living in bubbles during the coronavirus pandemic: insights from New Zealand. Rapid Research Report. London School of Economics and Political Science, London, UK. Available from: http://eprints.lse.ac.uk/id/ eprint/104421

Miller, G.A. (1956). The magical number seven, plus or minus two: some limits on our capacity for processing information. Psychological Review, 63(2), 81-97. https://doi.org/10.1037/h0043158

Moloney, K., \& Moloney, S. (2020). Australian Quarantine Policy: From Centralization to Coordination with mid Pandemic COVID-19 Shifts. Public Admin Rev. Accepted Author Manuscript. https://doi.org/10.1111/puar.13224

Novikova-Grund, M.V. (2011). Psihosemiotika: Analiz teksta v psihologii i psihoterapii [Psychosemiotics: Text Analysis in Psychology and Psychotherapy]. LAP LAMBERT Academic Publishing [in Russian].

Nussbaumer-Streit, B. et al. (2020). Quarantine alone or in combination with other public health measures to control COVID-19: a rapid review. Cochrane Database of Systematic Reviews, 4. Art. No.: CD013574. https://doi.org/10.1002/14651858. CD013574

Parmet, W.E., \& Sinha, M.S. (2020). Covid-19 - The Law and Limits of Quarantine. The New England Journal of Medicine, 382:e28. https://doi.org/10.1056/ NEJMp2004211

Reich, W. (1990). Character Analysis ( $3^{\text {rd }}$ ed., trans. Vincent R. Carfagno). New York: Farrar, Straus and Giroux. 
Study of the Covid-19 Related Quarantine Concept as an Emerging...

Rosenwald, M.S. (2020). History's deadliest pandemics, from ancient Rome to modern America. Washington Post. Available from: https://www.washingtonpost.com/ graphics/2020/local/retropolis/coronavirus-deadliest-pandemics/

Saussure, F. (1959). Course in general linguistics. New York, Philosophical Library.

Shymko, V., \& Babadzhanova, A. (2020). Study of the COVID-19 related quarantine notion as the language consciousness category on the sample of Russian speaking Ukrainians. Harvard Dataverse. https://doi.org/10.7910/DVN/Y2YGH7

Sorooshian, S. (2020). Quarantine Decision due to Coronavirus Pandemic. Electron Journal of General Medicine, 17(4):em206. https://doi.org/10.29333/ejgm/7862

Suresh, L.B. (2020). Back to Basics: Understanding Hand Hygiene and Quarantine. International Journal for Innovative Research in Multidisciplinary Field, 6(4), 245-251. Available from: https://www.ijirmf.com/wp-content/uploads/ IJIRMF202004044.pdf

Volpert, V. et al. (2020). On a quarantine model of coronavirus infection and data analysis. Mathematical Modelling of Natural Phenomena, 15(24). https://doi. org $/ 10.1051 / \mathrm{mmnp} / 2020006$

Wanga, H. et al. (2020). Social Distancing: Role of Smartphone During Coronavirus (COVID-19) Pandemic Era. International Journal of Computer Science and Mobile Computing, 9(5), 181-188. Available from: https://ijcsmc.com/docs/ papers/May2020/V9I5202016.pdf

Webster, R.K. et al. (2020). How to improve adherence with quarantine: rapid review of the evidence. Public Health, 182, 163-169. https://doi.org/10.1016/j. puhe.2020.03.007

Wilder-Smith, A., \& Freedman, D.O. (2020). Isolation, quarantine, social distancing and community containment: pivotal role for old-style public health measures in the novel coronavirus $(2019-\mathrm{nCoV})$ outbreak. Journal of Travel Medicine, 27(2):taaa020. https://doi.org/10.1093/jtm/taaa020

\begin{abstract}
АННОТАЦИЯ
Цель исследования. Исследование концепта коронавирусного карантина как новой категории языкового сознания украинцев.

Методики исследования. Стратегия проведенного изучения основывается на логико-методологической концепции индуктивизма. Респондентам было предложено письменно изложить собственное понимание карантина, сформулировав соответствующее определение, и описать ситуацию, которая на их взгляд является полной его противоположностью. Также респонденты оченивали, насколько изменилось их психологическое самочувствие, повседневный образ жизни во время карантина и ранжировали предпочтительность, предложенных им, карантинных стратегий. К полученным текстам был применен дискурсивный анализ, в результате чего выделено девять дискурсов. Указанные данные вместе с некоторыми сочио-демографическими характеристиками были подвергнуты многомерной математико-статистической обработке.
\end{abstract}

Результаты. Коронавирусный карантин представлен в языковом сознании дискурсивным полем, которое включает девять распознаваемых, семантически автономных дискурсов. Эмпирически зафиксировано такое 
явление, как междискурсная семантическая диссоциация. Его суть заключается в статистически достоверном снижении вероятности появления в текстах одних дискурсов при актуализации других. Данная особенность связана с негативизмом языка и обуславливает тенденциозность семантического наполнения концепта карантин. Междискурсная семантическая диссоциация, а также влияние не дискурсивных фракторов конституируют дискурсивную формацию концепта карантин, качественно характеризующуюся иерархичностью связей ее компонентов. Одновременно с этим выявлено, что часть диссоциативно взаимодействующих "по горизонтали» дискурсов, опосредованно ассоциированы "вертикально», чем формируют устойчивое семантическое ядро концепта карантин. Найдено частичное эмпирическое подтверждение ранее выдвинутых предположений о: (a) наличии такой взаимосвязи между дискурсами и механизмами психологических защит (как характерообразующих факторов), которая вносит вклад в иерархическое структурообразование дискурсивных фрормаций; (б) дифрреренциальности взаимодействия дискурсов и механизмов психологических защит, что позволяет выделять в характерологчческом профиле дискурсивный аспект и рассматривать дискурс в качестве оператора характерологической семантики. Выводы. Проведенное эмпирическое исследование позволило сформировать первичное представления о содержательных и структурных особенностях концепта карантин как новой категории сознания украинцев. Полученные результаты имеют потенциально полезную прикладную перспективу. Так, при проведении противоэпидемиологчческих мероприятий важно учитывать изученные особенности иерархической структуры дискурсивной формации концепта карантин, поскольку дискурсивная семантика связана с когнитивной фокусировкой, которая, в свою очередь, влияет на направленность и результаты поведения.

Ключевые слова: языковое сознание, семантика, дискурс, карантин, Covid-19, диссоциация, характер.

\section{Шимко Віталій \& Бабаджанова Анжела. Дослідження концепту коронавірусного карантину як нової категорії мовної свідомості}

\section{АНОТАЦІЯ}

Мета дослідження. Дослідження концепту коронавірусного карантину як нової категорії мовної свідомості українців.

Методики дослідження. Стратегія проведеного вивчення грунтується на логіко-методологічній концепції індуктивізму. Респондентам було запропоновано письмово викласти власне розуміння карантину, сформулювавши відповідне визначення та описати ситуачію, яка, на їхній погляд, $\epsilon$ повною його протилежністю. Також респонденти оцінювали, наскільки змінилося їхнє психологічне самопочуття, повсякденний спосіб життя під час карантину й ранжували уподобання щодо запропонованих їм карантинних стратегій. До отриманих текстів був застосований дискурсивний аналіз, в результаті 
чого виділено дев'ять дискурсів. Зазначені дані разом з деякими соціальнодемографрічними характеристиками були піддані багатовимірної математикостатистичній обробці.

Результати. Коронавірусний карантин представлено в мовній свідомості дискурсивним полем, яке включає принаймні дев'ять дискурсів, які розпізнаються та є семантично автономними. Емпірично зафіксовано таке явище, як міждискурсна семантична дисоціація. Його суть полягає в статистично достовірному зниженні ймовірності появи в текстах одних дискурсів при актуалізації інших. Дана особливість пов'язана з негативізмом мови й обумовлює тенденційність семантичного наповнення концепту карантин. Міждискурсна семантична дисоціація, а також вплив недискурсивних факторів конституюють дискурсивну формацію концепту карантин, котра якісно характеризується ієрархічністю зв'язків ії компонентів. Одночасно з цим виявлено, що частина дисоціативно взаємодіючих "за горизонталлю» дискурсів, опосередковано асочійовані "вертикально», чим формують стійке семантичне ядро концепту карантин. Знайдено часткове емпіричне підтвердження раніше висунутих припущень щодо: (а) наявності такого взаємозв'язку між дискурсами та механізмами психологічних захистів (як характероутворювальних факторів), який вносить вклад в ієрархічне структурування дискурсивних формацій; (б) диференційності взаємодії дискурсів і механізмів психологічних захистів, котра дозволяє виділяти в характерологічному профрілі дискурсивний аспект і розглядати дискурс в якості оператора характерологічної семантики. Висновки. Проведене емпіричне дослідження дозволило сформувати первинне уявлення про змістовні та структурні особливості семантики концепту карантин, як нової категорії свідомості українців. Отримані результати мають потенційно корисну прикладну перспективу. Так, при проведенні протиепідемічних заходів важливо враховувати вивчені особливості ієрархічної структури дискурсивної формації концепту карантин, оскільки дискурсивна семантика пов'язана з когнітивним фокусуванням, яке, в свою чергу, впливає на спрямованість і результати поведінки.

Ключові слова: мовна свідомість, семантика, дискурс, карантин, Covid-19, дисочіація, характер. 